\title{
Kajian Agronomis dan Kualitas Tepung Berbahan Ubi Kayu Lokal
}

\section{[Study of Agronomy Potential and Flour Quality of Local Types Cassava]}

\author{
Lucky Hartanti ${ }^{1)}$, Anang Syamsunihar ${ }^{2)}$, Ketut Anom Wijaya ${ }^{2)}$ \\ 1) Fakultas Pertanian UNTAN, JIn Prof. Hadari Nawawi Pontianak, 0561-765342 \\ 2) Fakultas Pertanian UNE] \\ Email: luckyhartanti.abubakar@yahoo.com
}

Diterima 4 September 2017/ Disetujui 2 November 2017

\begin{abstract}
Cassava flour has a good potential to substitute wheat flour for various food products and have a good opportunity to developed. The farmers prefer to cultivate local types of cassava compared to superior varieties national. Fresh cassavas contain cyanide acid $(\mathrm{HCN})$, which is harmful to health. Knowledge and skills in processing of cassava is needed to produce fresh cassava become safety product. The aimed of this research was to conducted to: 1) Examine the agronomic potential of local cassava as raw material for cassava flour industry , 2) Study quality cassava flour produced from three different types of local cassava. Cassava used in this study was a local type i.e.: "ketan", "Pb", "Sambung". The method of processing cassava flour was dried cassava method "gaplek", wet method "tapioka fermentation method "mocaf". In general all types of local cassava had a good agronomic potential and safe to be processed into cassava flour. Mocaf from "Pb" type gave the best result. The best tapioca was produced from "ketan" type of cassava.
\end{abstract}

Key Words: Cassava Flour, HCN, Local Types of Cassava

\section{ABSTRAK}

Tepung ubi kayu mampu menggantikan tepung terigu untuk berbagai produk pangan dan berpeluang bagus untuk dikembangkan. Petani lebih suka membudidayakan ubi kayu jenis lokal dibandingkan dengan varietas unggul nasional. Ubi kayu segar mengandung HCN yang berbahaya bagi kesehatan. Diperlukan teknik yang baik untuk mengolah ubi kayu menjadi produk yang aman dikonsumsi oleh masyarakat. Tujuan penelitian ini adalah: 1) Mengkaji potensi agronomis ubi kayu jenis lokal sebagai bahan baku industri tepung ubi kayu.2) Mengkaji kualitas tepung ubi kayu yang dihasilkandari tiga jenis ubi kayu lokal yang berbeda Ubi kayu yang dipakai dalam penelitian adalah ubi kayu lokal jenis ketan, $\mathrm{Pb}$ dan ubi sambung. Metode pengolahan tepung ubi kayu yang dilakukan adalah metode kering gaplek, metode basah tapioca dan metode fermentasi mocaf. Secara umum semua ubi kayu jenis lokal berpotensi agronomis dan aman untuk diolah menjadi tepung ubi kayu. Mocaf dari ubi jenis Pb memberikan hasil terbaik. Tapioka terbaik dihasilkan dari ubi kayu jenis ketan.

Kata Kunci :HCN, Tepung ubi kayu, Ubi kayu lokal

\section{PENDAHULUAN}

Ubi kayu merupakan bahan baku tepung yang sangat potensial, hal ini disebabkan kandungan karbohidrat dan patinya yang cukup tinggi.Dibandingkan ubi kayu segar, pemanfaatan ubi kayu dalam bentuk tepung lebih luas penggunaannya dan memiliki prospek yang baik jika dikembangkan sebagai bahan subtitusi tepung terigu. Teknologi sederhana pembuatan tepung ubi kayu sudah cukup dikenal di masyarakat, diantaranya tepung tapioka, tepung gaplek, dan mocaf.
Prinsip umum budidaya ubi kayu adalah penerapan hasta usaha tani, termasuk diantaranya penggunaan varietas unggul. Keberadaan ubi kayu jenis lokal lebih diterima oleh petani daripada ubi kayu varietas unggul.Ubi kayu jenis lokal memiliki potensi agronomis yang baik untuk dikembangkan sebagai bahan baku tepung ubi kayu.

Ubi kayu jenis sambung, ketan dan $\mathrm{Pb}$ merupakan ubi kayu jenis lokal berdaging putih yang sering dijumpai di Kecamatan Sumberbaru Kabupaten Jember. Di Jawa Timur budidaya ubi kayu sistem sambung memberikan hasil ubi yang beragam yaitu 
pada kisaran 33-59 ton/ha (Prasetiaswati et al., 2008). Hamdi et al. (1994), melaporkan ubi kayu ketan merupakan ubi kayu lokal yang banyak dijumpai di Sumatera dan Jawa dengan produktivitas 28,36 ton/ha. Ubi kayu jenis $\mathrm{Pb}$ adalah ubi kayu yang digemari oleh masyarakat Kecamatan Sumberbaru karena rasanya enak dan produktivitasnya tinggi 18-25 ton/ha.

Ubi kayu sebagai produk pertanian setelah dipanen tetap melakukan aktifitas fisiologisnya. HCN dikenal sebagai racun biru yang diproduksi secara alami oleh ubi kayu sebagai hasil dari aktifitas fisiologis. Crowder dan Chedda (1982) melaporkan kandungan $\mathrm{HCN}$ dalam suatu tanaman dipengaruhi faktor genetis, iklim, kesuburan tanah tempat tumbuh, dan umur tanaman. Kandungan $\mathrm{HCN}$ dalam ubi dapat diturunkan dengan teknik pengolahan yang tepat, salah satunya mengolah ubi kayu menjadi tepung.

Tujuan penelitian ini adalah mengkaji potensi agronomis tiga jenis ubi kayu lokal sebagai bahan baku industri tepung ubi kayu dan kualitas tepung ubi kayu yang dihasilkan. Manfaat penelitian ini adalah mendapatkan ubi kayu jenis lokalyang secara agronomis terbaik sebagai bahan tepung berkualitas.

\section{METODOLOGI PENELITIAN}

\section{Metode Percobaan}

Pembuatan tepung ubi kayu yang dikaji menggunakan 3 metode pengolahan antara lain cara kering yaitu pembuatan tepung gaplek, cara basah yaitu pembuatan tepung tapioka, dan cara fermentasi yaitu tepung MOCAF (Subagio, 2008).

Parameter pengamatan meliputi kadar air, kadar protein terlarut, kadar pati, kadar HCN ubi kayu dan tepung, suhu gelatinisasi tepung, viskositas tepung, derajat putih tepung, pengujian organoleptik mengenai aroma tepung ubi kayu. Dilakukan perbandingan kadar air, kadar protein, kadar pati dan kadar $\mathrm{HCN}$ antara ubi kayu lokal dengan ubi kayu varietas unggul dan antara tepung yang dihasilkan dengan SNI.

\section{Bahan dan Alat}

Bahan baku yang digunakan adalah ubi kayu berumur 9-10 bulan (umur panen optimal) dari jenis ketan, jenis $\mathrm{Pb}$ dan jenis sambung. Semua jenis ubi kayu tersebut ditanam dalam satu lahan dan mendapatkan perlakuan pemupukan dengan dosis pemupukan yang sama. Bahan kimia yang digunakan antara lain asam sitrat, $\mathrm{H}_{2} \mathrm{SO}_{4}$ pekat, aquadest, $\mathrm{NaOH}$, asam borat, metil merah dan $\mathrm{HCl}$, eter, alkohol $10 \%$, buffer phosphat $0,1 \mathrm{M} \mathrm{pH} \pm 6$.

Alat yang dipergunakan dalam penelitian ini meliputi pisau, oven, desikator, cawan petri, parut, timbangan digital, labu Kjedal, erlenmeyer, buret, kertas pikrat, mortal, beakerglass, pH meter, spektrometer, tabung reaksi, petridish, pipet tetes, pengaduk, termometer, hot plate stirer, viskometer VT01/02, penangas, dan color reader.

\section{Tempat Percobaan}

Analisis $\mathrm{HCN}$ dilakukan di Laboratorium Fisiologi Tumbuhan Jurusan Budidaya Pertanian Fakultas Pertanian Universitas Jember dan sedangkan pembuatan tepung dilaksanakan di Laboratorium Kimia dan Biokimia Hasil Pertanian Jurusan Teknologi Hasil Pertanian Fakultas Teknologi Pertanian Universitas Jember.

\section{Metode Analisis}

Pengukuran kadar air menggunakan metode termogravimetri, kadar protein dengan metode mikro Kjeldahl, kadar pati menggunakan metode Nelson-Soomogyi dan kadar HCN menggunakan metode kertas pikrat. Pengukuran suhu gelatinisasi dilakukan secara manual, pengukuran viskositas panas dan dingin menggunakan viscotester 01 , derajat putih menggunakan metode colour reader minolta RR-01, dan tingkat kesukaan pada aroma menggunakan uji organoleptik. Penentuan perlakuan terbaik pada semua perlakuan ditentukan berdasarkan indeks efektifitas (Garmo, 1984).

\section{HASIL DAN PEMBAHASAN}

\section{Kadar Air}

Kadar air ubi segar yang berumur 9 bulan berada di kisaran 60,31\%-63,70\% (Gambar 1). Kadar air ubi kayu varietas unggul Darul Hidayah, UJ-3 dan UJ-5 pada umur panen 8 hingga 10 bulan berada pada kisaran 55\%-65\% (Suhartina, 2005). Kadar air ketiga ubi kayu jenis lokal masuk dalam 
kisaran kadar air ubi kayuvarietas unggul.Susilawati et al., (2008) melaporkan kadar air ubi kayu segar dipengaruhi oleh tingkat kesuburan dan umur panen ubi kayu. Semakin subur tanah maka kadar air ubi kayu segar akan semakin tinggi dansemakin lama umur panen ubikayu maka semakin rendah kadar airnya.

Kadar air tepung pada semua jenis ubi kayu lokal pada semua metode pembuatan berada di kisaran 11,29\%$15,14 \%$ (Gambar 1). Kadar air tepung gaplek berada dikisaran 13,48\%-13,65\%. Berdasarkan SNI 1996 mengenai standar kualitas tepung gaplek,kadar air tepung gaplek yang baik berada pada kisaran $13 \%$. Pada standar mutu tepung tapioka SNI 01345-1996, kadar air maksimal tapioka adalah $15 \%$,sedangkankadar air tepung tapioka yang dihasilkan dalam penelitian ini berada pada kisaran 13,14\% $-13,96 \%$. Kadar air mocaf berada pada kisaran $10,89 \%-11,40 \%$.

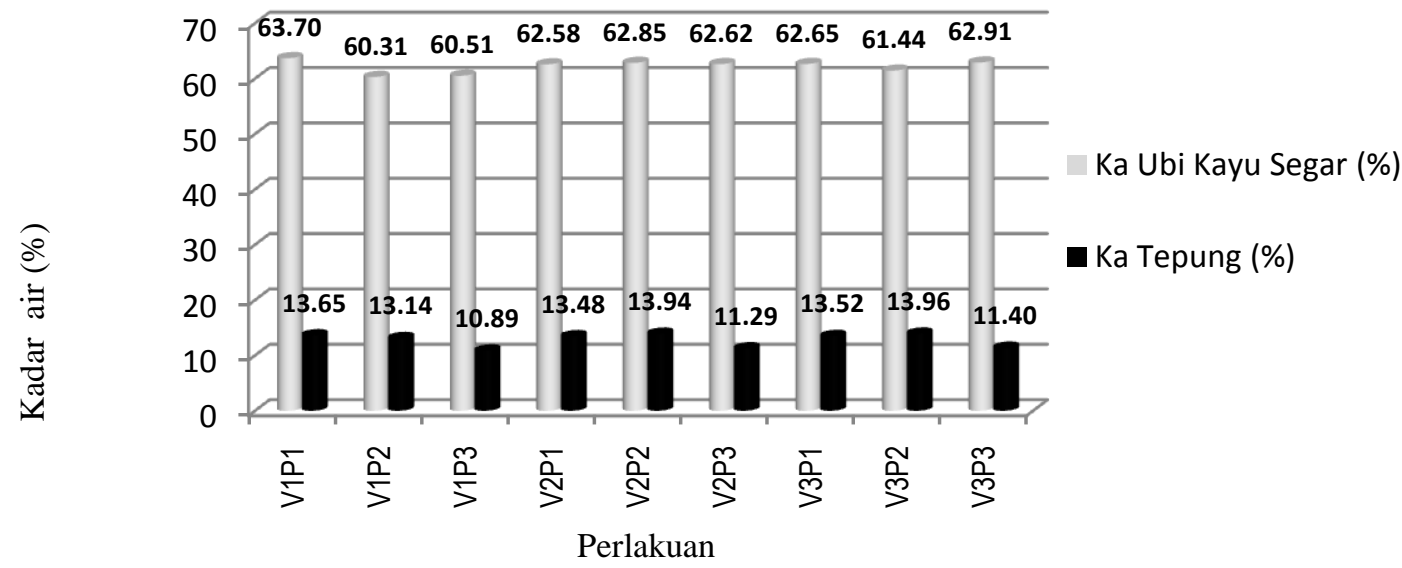

Gambar 1. Kadar Air Ubi Kayu Segar dan Kadar Air Tepung Ubi Kayu

Dalam CODEX STAN 176-1989 (Rev. 1-1995) kadar air maksimal tepung ubi kayu adalah 13\%. Berdasarkan data pengukuran kadar air pada semua jenis tepung ubi kayu yang dihasilkan telah memenuhi standart kualitas SNI yang berlaku. Hasil penelitian menunjukkan kadar air tepung terbaik diperoleh pada tepung mocaf dari jenis ubi ketan sebesar $10,89 \%$ dan tepung mocaf dari jenis $\mathrm{Pb}$ putih sebesar $11,29 \%$.

\section{Kadar Protein}

Kadar protein ubi kayu jenis lokal umur panen 9 bulan berada di kisaran 0,5\%-0,9\% (Gambar 2), sedangkan kadar protein ubi kayu varietas unggul Malang-1, Malang-2 dan Adira-1 0,5\%, Adira-2 0,7\%, Adira-4 0,8\% (Suhartina, 2005). Kadar protein ubi kayu jenis lokalsetara dengan kadar protein ubi kayu varietas unggul.Kandungan protein dalam tanaman dipengaruhi oleh pemupkan serta kandungan $\mathrm{N}$ dalam tanah. Tanaman umbiumbian yang tidak dipupuk $\mathrm{N}$ menghasilkan umbi dengan kadar protein rendah (Suminarti, 2010). Menurut Crowder dan Chedda (1995) kadar protein akan menurun sesuai dengan meningkatnya umur tanaman dan kadar serat.

Tepung ubi kayu dengan kadar protein tertinggi diperoleh pada perlakuan tepung gaplek dari semua jenis ubikayu yaitu pada kisaran 2,39\%-2,47\% (Gambar 2). Berdasarkan standart kualitas tepung gaplek SNI 01-2997-1996, kadar protein minimal sebesar 1,2\%. Dibandingkan dengan tepung gaplek, tepung mocaf memiliki kandungan protein terendah berada pada kisaran 1,2\%-1,4\%hal ini disebabkan dalam pembuatan mocaf terjadi proses pemanfaatan nitrogenoleh mikroba selama proses fermentasi sehingga menurunkan kadar protein mocaf. 


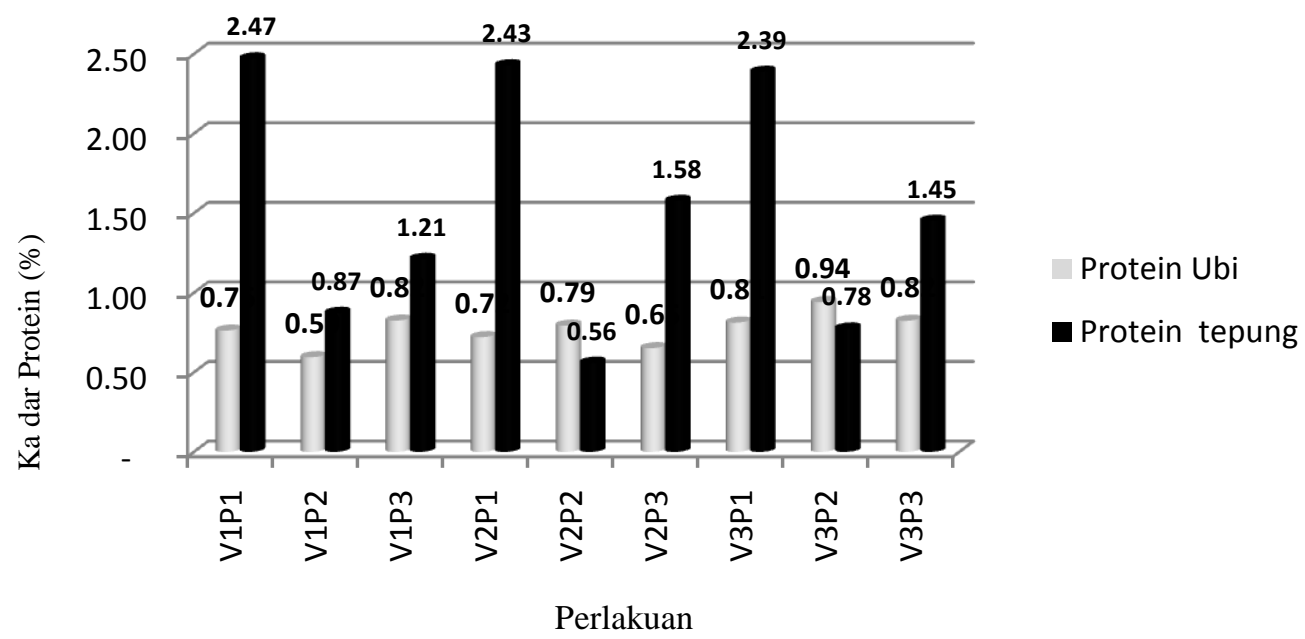

Gambar 2. Kandungan Protein Ubi Kayu Segar dan Tepung Ubi Kayu

\section{Kadar Pati}

Kadar pati dalam ubi kayu segar berada pada kisaran 23,19\%-27,74\% (Gambar 3). Kadar pati ubi kayu sangat dipengaruhi oleh umur panen, varietas, lokasi tanam dan iklim. Suhartina (2005) melaporkan kandungan pati varietas unggul
Adira-4, Malang-1, Malang-2, Malang-4, Malang-6, Darul Hidayah, UJ-3, UJ-5, berada pada kisaran 17\%-36\%. Semua kadar pati ubi kayu jenis lokal setara dengan kisaran kandungan pati ubi kayu varietas unggul.

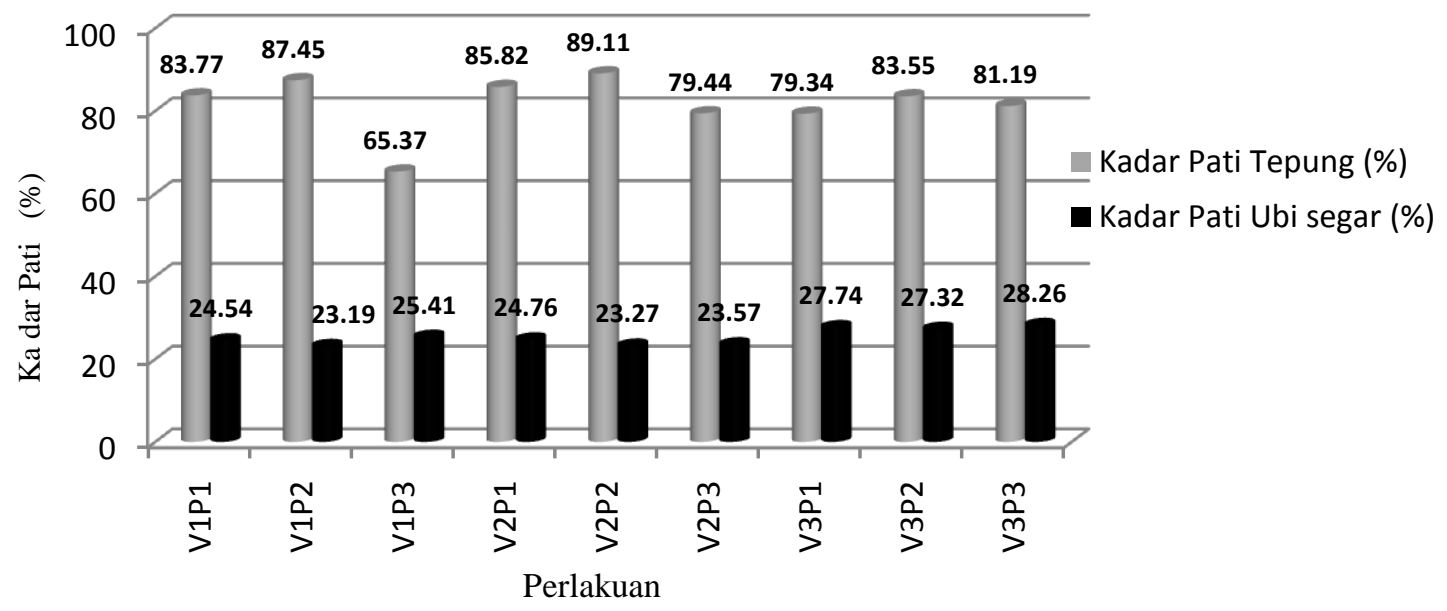

Gambar 3. Kadar Pati Ubi Kayu Segar dan Tepung Ubi Kayu

Terjadi peningkatan kadar pati yang sangat tinggi setelah ubi segar diproses menjadi tepung. Tepung tapioka dari ubi $\mathrm{Pb}$ memiliki kadar pati tertinggi sebesar $89,11 \%$, kadar patitepung gaplek di kisaran $83,774 \%-87,446 \%$ (Gambar 3). Berdasarkan standart kualitas tepung gaplek SNI 1996, kandungan pati miniman $70 \%$. Kadar pati tepung gaplek masuk dalam standart kualitas yang ditentukan pasar. Mocaf memiliki kadar pati yang terrendah karena selama fermentasi pada pembuatan tepung mocaf terjadipemanfaatan karbon oleh mikroba.

\section{Kadar Sianida}

Kandungan $\mathrm{HCN}$ semua ubi kayu segar di kisaran 4,2 ppm-24,2 ppm (Gambar 4), ketiga jenis ubi kayu lokal merupakan ubi kayu yang tidak pahit. Rasa pahit merupakan indikator kadar HCN yang tinggi. HCN dalam ubi kayu merupakan sifat fenotipe dari tanaman yang merupakan penggabungan faktor genetis dan faktor lingkungan. Wahjuningsih (2012) 
melaporkan varietas ubi kayu memberikan pengaruh nyata terhadap kadar $\mathrm{HCN}$ tepung ubi kayu.Sementara, faktor lingkungan, khususnya curah hujan yang rendah akan meningkatkaan kandungan HCN dalam umbi ubi kayu bahkan kandungan $\mathrm{HCN}$ tepung ubi kayu (Cardoso et al., 1999).

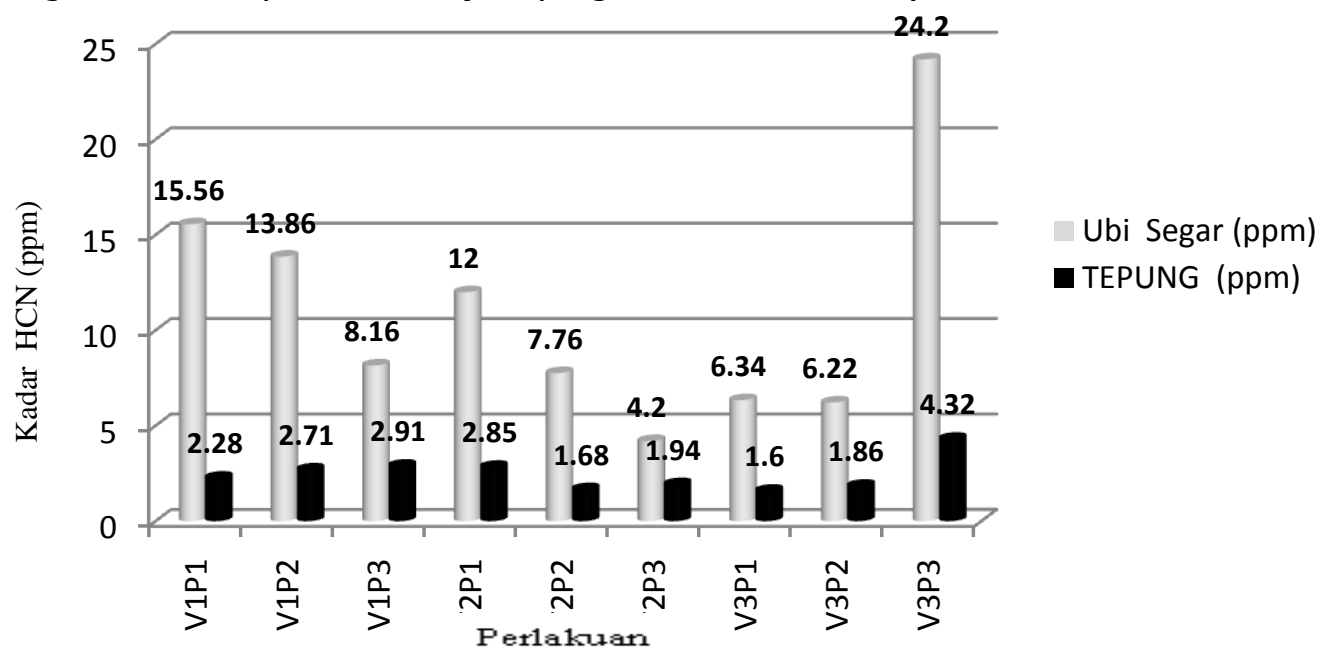

Gambar 4.Kandungan HCN Ubi Kayu Segar Dan Tepung Ubi Kayu

Dalam CODEX STAN 176-1989 (Rev. 1-1995) dan rekomendasi WHO kadar $\mathrm{HCN}$ tepung ubi kayu yang aman dikonsumsi adalah $10 \mathrm{ppm}$ (Subagioet al., 2008). Kadar HCN tepung ubi kayu yang dihasilkan dalam penelitian ini berada di kisaran 1,6-4,32 ppm. Seluruh tepung ubi kayu yang dihasilkan dalam penelitian ini sesuai standar kualitas kandungan $\mathrm{HCN}$ dan aman dikonsumsi.

Persentase penurunan kadar $\mathrm{HCN}$ ubi segar setelah diolah menjadi tepung dengan berbagai metode yang diuji pada ketiga jenis ubi sangat signifikan, lebih dari $50 \%$ (Gambar 5). Tepung gaplek dari jenis ketanmemiliki nilai penurunan yang tertinggi sebesar $85,35 \%$. Setiap tahap pengolahan dalam pembuatan tepung memberikan pengaruh terhadap kadar HCN tepung ubi kayu. Cardoso et al., (1999) melaporkan pengolahan ubi kayu berpotensi menurunkan 67\%-98,7\% kandungan $\mathrm{HCN}$ pada ubi kayu segar.

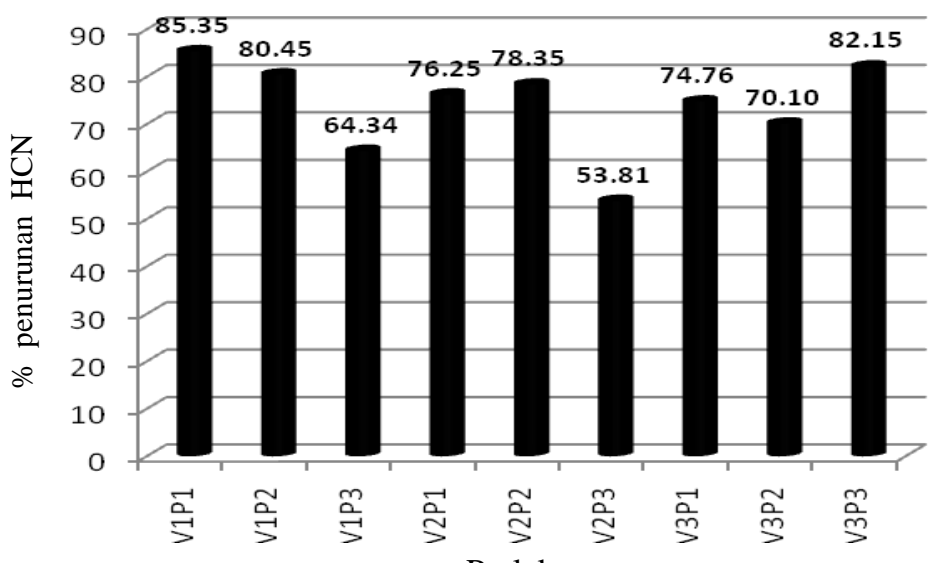

Gambar 5. Persentase penurunan kadar HCN darí ubi kayu segar menjaditepung ubi kayu

\section{Gelatinisasi}

Suhu gelatinisasi tepung gaplek dari tiga jenis ubi kayu lokal pada kisaran suhu $66^{\circ} \mathrm{C}-68^{\circ} \mathrm{C}$, sedangkan tepung tapioka $68^{\circ} \mathrm{C}$ dan tepung mocaf berada pada kisaran $65^{\circ} \mathrm{C}-68{ }^{\circ} \mathrm{C}$ (Gambar 6). Suhu gelatinisasi tepung ubi kayu yang baik berkisar antara $65-70^{\circ} \mathrm{C}$. Perbedaan suhu gelatinisasi biasa terjadi, karena tidak semua granula pati 
tergelatinisasi pada titik yang sama, tetapi terjadi pada suatu kisaran suhu tertentu.

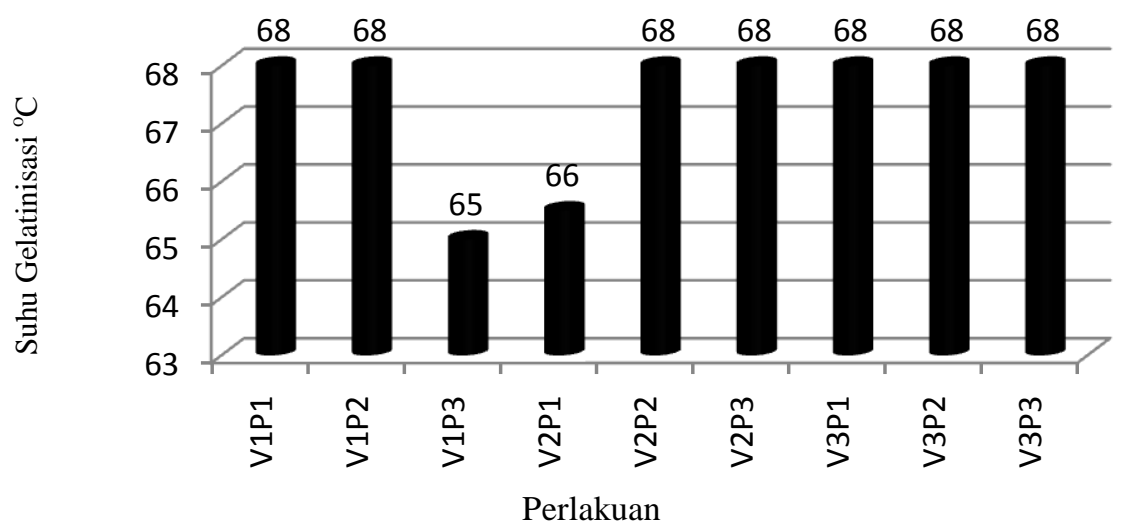

Gambar 6. Suhu Gelatinisasi Tepung Ubi Kayu

\section{Viskositas}

Tepung tapioka dari jenis ubi kayu sambung memiliki viskositas yang tertinggi 32 mPa.s (Gambar 7). Viskositas tepung tapioca semua jenis ubi kayu lokal memiliki nilai yang lebih tinggi dibandingkan tepung gaplek dan mocaf. Diduga pati tepung tapioka memiliki kandungan serat lebih sedikit dari tepung gaplek dan tepung mocaf. Menurut Subagio et al. (2008), dalam tepung tapioka komponen patinya mencakup hampir seluruh bahan kering.

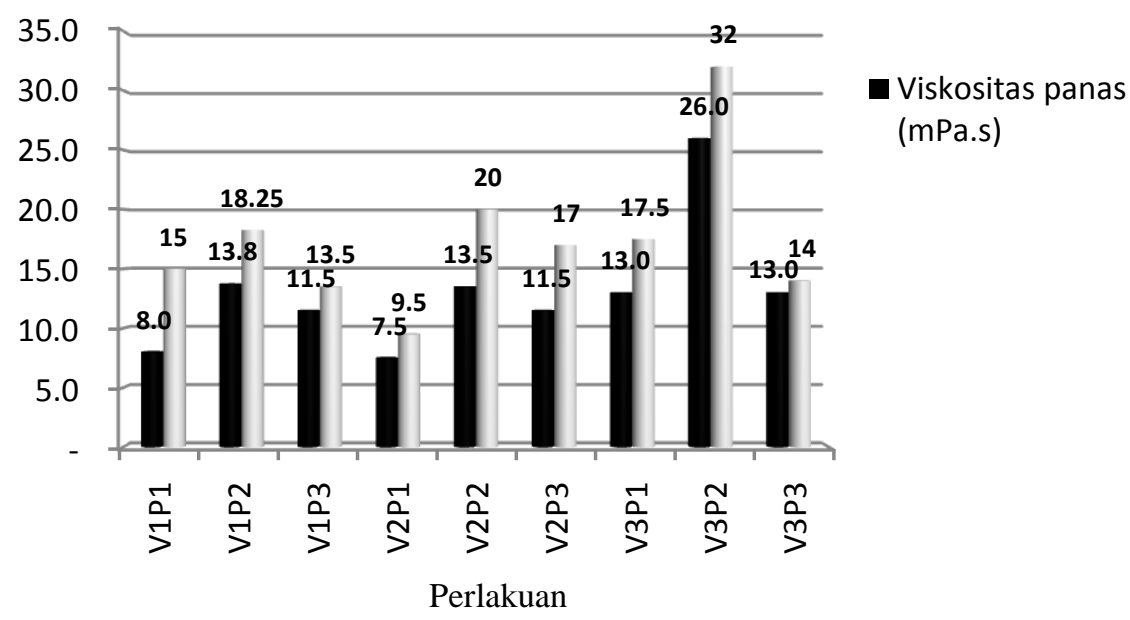

Gambar 7. Viskositas Panas dan Dingin Tepung Ubi Kayu

Tapioka memiliki granula pati lebih banyak, ketika terjadi gelatinisasi granula pati inilah yang akan membesar dan memerangkap air dalam jumlah yang lebih banyak dan larutan akan semakin kental serta visikositas akan meningkat. Nilai viskositas dingin semua tepung lebih tinggi dibandingkan viskositas panasnya, hal ini mengindikasikan bahwa produk yang terbentuk dari tepung tersebut memiliki tekstur lebih lunak/empuk pada kondisi panas dibandingkan dengan pada kondisi dingin. Semua perlakuan tepung tapioka yang diuji memiliki viskositas dingin yang tinggi hal ini dikarenakan kandungan amilopektin yang terdapat di dalamnya lebih tinggi dibandingkan dengan tepung gaplek dan tepung mocaf.

\section{Derajat Putih}

Kandungan protein dalam tepung akan berpengaruh terhadap derajat putih tepung ubi kayu. Peningkatan derajat putih berkaitan dengan berkurangnya reaksi maillard yang terjadi di dalam tepung ubi kayu (Subagio et al., 2008).

Hasil penelitian menunjukkan tepung tapioka dari jenis ubi sambung memiliki derajat putih tertinggi di kisaran 90,38\%-92,77\% (Gambar 8). Tepung tapioka mempunyai kandungan protein yang paling rendah sehingga memiliki 
warna paling putih, selanjutnya tepung mocaf, dan tepung gaplek mempunyai kandungan protein tertinggi dengan derajat putih yang terrendah $81,53 \%-82,31 \%$. Tepung mocaf memiliki derajat putih pada kisaran 87,43\%-89,97\%. Menurut SNI 012997-1996 derajat putih tepung ubikayu minimal $85 \%$, artinya tepung mocaf dan tapioka dari tiga ubi kayu jenis lokal masuk dalam standart yang berlaku.

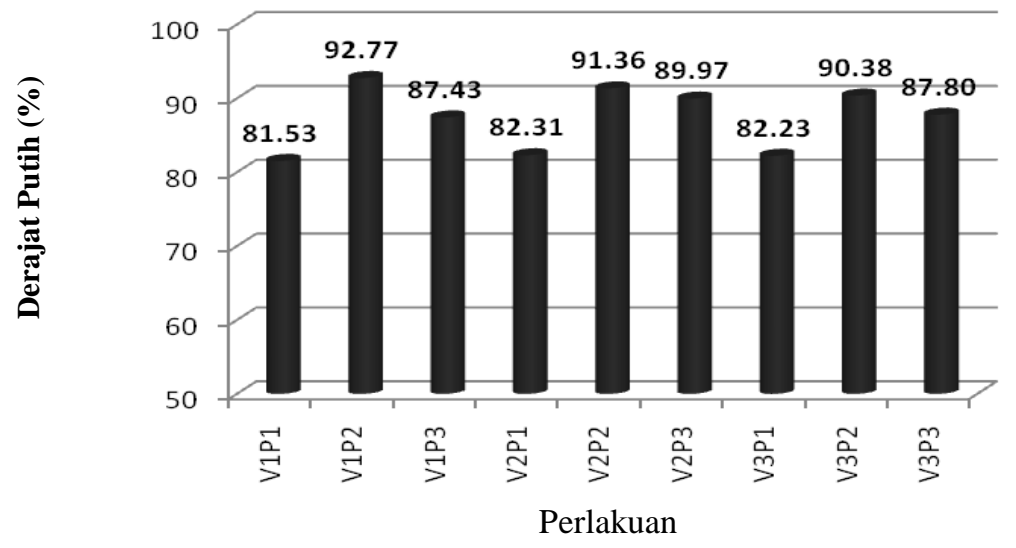

Gambar 8.Derajat Putih Tepung Ubi Kayu

\section{Aroma}

Aroma aroma tepung tapiokamemiliki skor tertinggi yaitu berada pada kisaran 3,75-3,9 (aroma sedikit khas ubi kayu sampai sangat sedikit aroma ubi kayu), selanjutnya aroma tepung mocaf dengan kisaran skor 3,5-3,65 (aroma sedikit khas ubi kayu sampai sangat sedikit aroma ubi kayu) dan tepung gaplek memiliki skor yang terrendah dengan kisaran 2,9-3,45 (aroma khas ubi kayu sampai sangat sedikit khas ubi kayu (Gambar 9). Pada tepung gaplek masih tercium aroma khas ubi kayu,sedangkan pada tepung tapioka dan mocaf aroma ubi kayu sudah sangat berkurang.

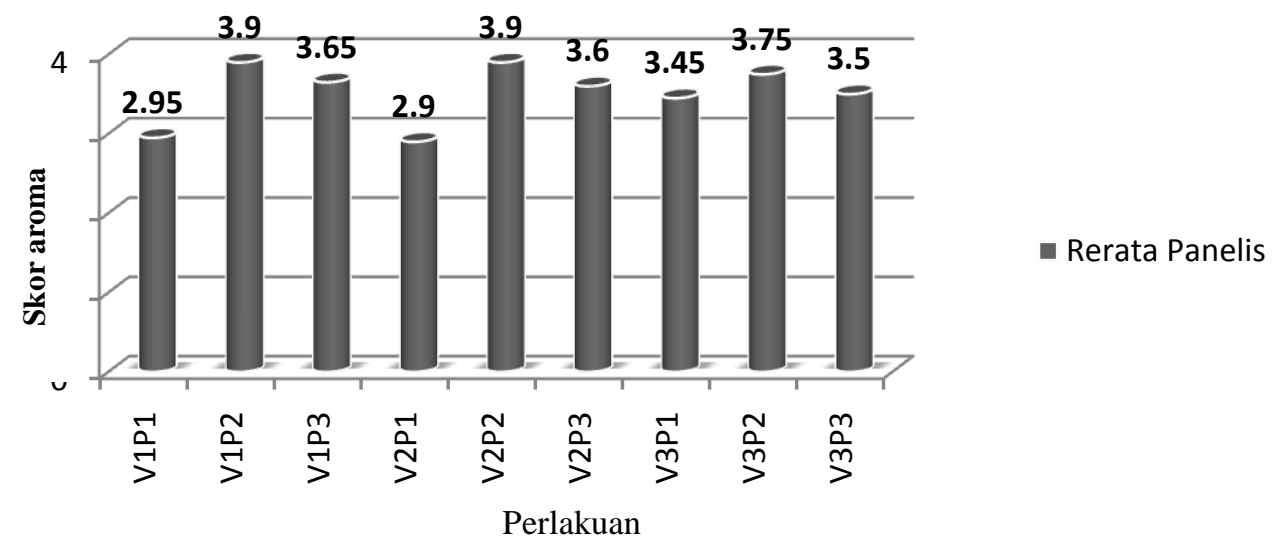

Gambar 9.Tingkat kesukaan aroma tepung ubi kayu

Proses pembuatan mocaf dapat menutupi aroma dan citarasa ubi kayu sampai $70 \%$ yang cenderung kurang disukai konsumen. Hal ini karena hidrolisis granula pati menghasilkan monosakarida sebagai bahan baku penghasil asam-asam organik, terutama asam laktat yang akan terimbibisi dan bercampur dengan tepung (Subagio et al., 2008).

\section{Uji Efektifitas}

Pengujian efektifitas pada parameter kualitas tepung ubi kayu dari tiga jenis lokal ubi kayu tersaji pada Gambar 10, bahwa ubi kayu jenis $\mathrm{Pb}$ memiliki efektifitas terbaik untuk diolah menjadi tepung mocaf dan tepung tapioka. Demikian halnya dengan ubi kayu jenis ketan yang memberikan hasil 
yanç L-:"k bila diolah menjadi tepung tapioka.

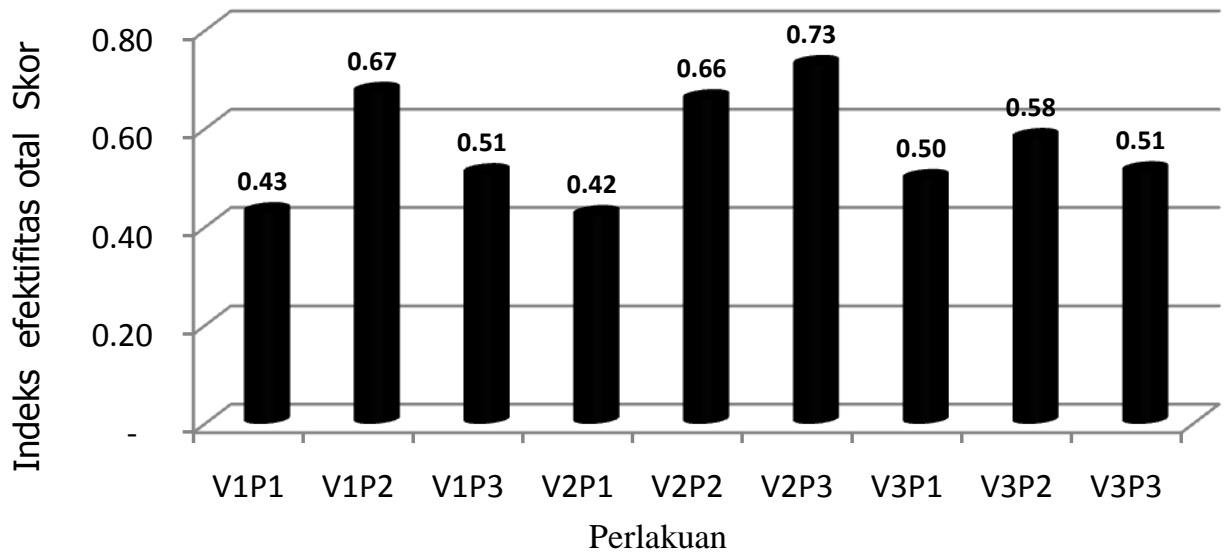

Gambar 10. Tingkat Efektifitas Metode Pengolahan Tepung pada Ketiga Jenis Ubi Kayu Lokal

\section{Kesimpulan}

\section{KESIMPULAN DAN SARAN}

Berdasarkan hasil percobaan yang telah dilakukan maka dapat disimpulkan bahwa (1) ketiga ubi kayu jenis lokal yang diuji memiliki potensi sebagai bahan baku industri tepung ubi kayu yang bergizi dan aman untuk dikonsumsi sesuai standart perdagangan tepung secara nasional, (2) hasil Uji Efektifitas menunjukkan bahan tepung terbaik diperoleh dari ubi jenis $\mathrm{Pb}$ dengan teknik mocaf,sedangkan ubi kayu jenis ketan dan jenis sambung memberikan hasil terbaik untuk pembuatan tepung tapioka.

\section{Saran}

Penelitian lanjutan yang dapat dilakukan untuk mendapatkan informasi yang lebih baik lagi adalah mengkaji potensi ubi kayu lokal lainnya dan varietas unggul sebagai bahan pembuat tepung dengan tinjauan agronomisnyadan menggunakan metode penelitian yang lebih komprehensif dengan pembanding tepung terigu.

\section{DAFTAR PUSTAKA}

Cardoso AP, Ernesto M, Cliff J, dan Bradbury JH. 1999. High levels of total cyanogens in cassava. our related to drought in Mozambique. Roots 6, 4-6.
Crowder L, dan Chedda HR. 1982. Tropical Grassland Husbandry Husbandry. 11st edition. New York : Longman.

Garmo D, Sullivan WG, dan Canada J. 1984, Engineering Economy. New York: MacMillan Publishing Company.

Hamdi, Jonharnas, Nasri M, Zulyani, dan Jusuf. 1994. Adaptasi dan Stabilitas Hasil Klon-klon Harapan di Beberapa Lokasi, Balai Penelitian Tanaman Pangan, Sukarami.

Prasetiaswati N, Santoso BR, dan Saleh. 2011. Kelayakan Usahatani Ubikayu Sambung Randan I pada Berbagai Dosis Pupuk. Prosiding Seminar Hasil Penelitian Tanaman Aneka Kacang dan Umbi 2011. Malang: Balai Penelitian Tanaman Kacangkacangan dan Umbi-umbian Malang.

SNI. 1996. Tepung Singkong. Jakarta: Badan Standardisasi Nasional.

Subagio, Siti W, Wibowo Y, dan Fahmi F. 2008. Prosedur Operasi Standar (POS) Produksi MOCAL Berbasis Klaster. Bogor: Southeast Asian Food and Agricultural Science and Technology (SEAFAST) Center. Istitut Pertanian Bogor.

Sudarmadji S, Haryono B., dan Suhardi. 1997. Prosedur Analisa untuk Bahan 
Makanan dan Pertanian. Yogyakarta: Liberty

Suhartina. 2005. Deskripsi Varietas Unggul Kacang-kacangan dan Umbi-umbian. Malang: Balai Penelitian Tanaman Kacang-kacangan dan Umbi-umbian.

Suminarti NE. 2010. Pengaruh Pemupukan $\mathrm{N}$ dan $\mathrm{K}$ pada Pertumbuhan dan Hasil Tanaman Talas yang Ditanam di Lahan Kering. Akta Agrosia. 13(1).
Susilawati, Nurdjanah S, dan Putri S. 2008. Karakteristik Sifat Fisik dan Kimia Ubi Kayu (Manihot esculenta) Berdasarkan Lokasi Penanaman dan Umur Panen Berbeda. Jurnal Teknologi Industri dan Hasil Pertanian. 13(2).

Wahjuningsih SB. 2012. Kajian Pembuatan Tepung Mokal dengan Metoda Biang Dari Berbagai Varietas Ubi Kayu (Manihot esculenta Crantz). Prosiding Seminar Nasional FAI 2012 ISBN: 978-602-18810-0-2 